\title{
Supermodernity and Archaeology
}

Alfredo González-Ruibal

\section{Introduction and definition}

The term supermodernity (surmodernité) was coined by French Anthropologist Marc Augé in 1992 to define the period commonly known as late modernity. The usefulness of the concept of supermodernity, as compared to other definitions of the later part of modernity, rests on two things: the idea of exaggeration and the retention of the concept of modernity. Regarding the first point, Augé (2002: 26-45) talks of three excesses: factual overabundance (which is associated with an acceleration of historical time), spatial overabundance (the abolishing of distance by electronic media and transportation), and an excess of self-reflexive individuality. We can add a fourth excess: material overabundance. In relation to the idea of modernity that Augé keeps in his definition, it can be said that while some of the notions of modernity might seem to be outdated, as the defendants of postmodernity argue, its core categories are certainly not. I consider that postmodernity is, in fact, a period characterized by an awareness of the risks and flaws of being modern, but which has not been able to overcome modernity's troubles. Our current concern with ecological and social catastrophe at a global scale is the demonstration that the process started during the 15th century is far from finished: we are probably just witnessing its climax.

\section{Key issues/Current debates}

The term "supermodernity", then, captures well the essence of our present period of modern exaggeration. Another question is when to start such a period. Augé does not give clear indications, although it is implicitly understood that it covers the same timespan that others identify with post-, high, late or liquid modernity (Giddens 1991; Jameson 1991; Bauman 2000) and which begins around the end of the Second World War or later depending on the authors. This is the periodization that some researchers follow to define the archaeology of the contemporary as the study of the time that goes “after modernity” (Harrison and Schofield 2010). Although trying to parcel time may seem to be a fruitless historicist exercise, I think that it can also be a way of reflecting 
on history and time differently. What we need is a periodization of modernity that fits the archaeological record. It is necessary to privilege in our periodizations not the phenomena identified by sociologists, culture historians or philosophers, but the processes of creation and destruction of matter that archaeology has traditionally employed to make sense of time and change. We have to follow the time(s) of things (Olivier 2008: 247-252).

From this point of view, a moment that seems best suited to start supermodernity is the early twentieth century. It has been pointed out that the transition between the late nineteenth and the early twentieth century inaugurates a period in which globalization reaches its first apex and becomes truly global. Globalization is not just the circulation of people, images or ideas, it is also (perhaps primarily) the circulation of material objects. This was made possible by technologies of transport and communication that abolished distance in the service of an ever-expanding global capitalism (Harvey 1990). The materiality of the world became more and more integrated-more and more similar-and the mass-production of objects played an outstanding role in this process. More importantly, and perhaps not sufficiently appraised, the period that begins in 1914 is marked by mass-destruction of human lives, societies, things and the environment at an unprecedented scale in the history of humankind. Interestingly, although the relationship between globalization, production and consumption has often been emphasized, the globalization of death has been less discussed. Thus, historians agree that the 1914-1945 period witnessed the collapse of the first globalization (Obstfeld and Taylor 2003: 125-126) as opposed to the late nineteenth century, but this is only the case if we pay attention to the movement of free citizens, capital and consumer goods. If we look at the circulation of soldiers, refugees, war machinery and destruction, 19141945 is actually a period of astonishing global integration (FIGURE 1). High explosive has probably contributed as much to globalization as Coca-Cola, if not more.

In fact, should supermodernity end tomorrow, it would be perfectly identifiable from an archaeological point of view thanks to global destructive processes. The things that demand the attention of intellectual gurus, social commentators, and their many followers seem somewhat banal compared to other issues that are leaving an indelible archaeological imprint in the world. In the long run, postmodern architecture would seem just like an anecdote (like the difference between baroque and rococo) and without new media the pace of global integration and social change would perhaps be a little bit slower, but it would happen nonetheless. It is on the destructive operations of 
supermodernity that archaeology can provide a distinct and necessary critical perspective. After all, the transformations that archaeology documents more easily are changes in material organisations with high irreversibility (Lucas 2008), and these are also the ones that have further-reaching consequences historically: consider the collapse of the communist regimes, the Second World War or the end of peasant societies, all of which have left a wake of razed landscapes behind.

If instead of looking at destruction, we focus on creation, the situation is not different. The supermodern landscapes of creation (Penrose 2007) are also landscapes of oblivion and devastation. Urbicide is not only inflicted during wars (Coward 2008), it can also take the shape of urban renewal (Mullins 2006). In fact, destruction and construction should not be opposed; they are inextricably linked. This is obvious in slash-and-burn agriculture: the forest is felled, burnt down, and cultivated, but later the fields are fallowed and the trees revive with further strength. Similarly, the Neolithic houses of Anatolia and the Balkans were regularly destroyed only to be rebuilt again, energized by the seeds of the ancestors. The Neolithic probably marks the beginning of the strong interdependence between construction and destruction, death and the regeneration of life (Stevanovic 1997; Kuijt 2008). In this context, the destruction of houses would be "a matter of continuity rather than ending” (Hodder 2010: 150). It is not strange that this rationality emerged with the appearance of cultivation, which is also based on cycles of life and death.

Yet with modernity, this logic is no longer sustainable: unlike in Neolithic and other nonmodern societies (e.g. Küchler 2002), destruction is no longer a form of continuity, regeneration and remembrance, but of rupture and forgetting. Destruction is neither a form of creating and maintaining relations, but of cutting them off: death has become an end in itself. In nonmodern societies, even war and predation are ways of extending relations (Harrison 1993, Fausto 1999). The change in the nature of destruction in supermodernity is no better exemplified than in the mass-production of nuclear weapons that can wipe out the entire humanity: death for death's sake. Robert Oppenheimer's words epitomize the sense of a new age of total destruction: "Now, I am become Death, the destroyer of worlds". Oppenheimer's famous misquotation is meaningful: the original cite from the Bhagavad-gita is "I am become Time, the destroyer of worlds”. But Time can no longer destroy things with its slow rhythm as it used to. Augé (2003: 110) says that "only a catastrophe can produce today comparable effects to the slow action of time”. Only Hiroshima or Katrina. 


\section{Spatial excess}

One of the points that makes Marc Augé's definition appealing for archaeologists is his concern with places. According to Augé (2002) the time of supermodernity is marked by a shift from places to non-places: "If place can be defined as relational, historical and concerned with identity, a space that cannot be defined as a relational, historical or concerned with identity can be defined as a non-place” (Augé 2002: 83). Non-places do not foster symbolic relationships or a shared heritage. Their purpose is only to facilitate circulation and consumption in a global world (Augé 2003: 101). Non-places have all the appearance of a dejà-vu, which is not innocent: their mission is precisely to neutralize the sense of alienation in a foreign environment (Harrison and Schofield 2010: 256). They eliminate the place-ness of places. Airports, highways, malls and hotels are typical non-places. Elsewhere, Augé (2003: 71) distinguishes between two categories: non-places of refuge and non-places of image (simulacra). The non-places of refuge are related to emigration and escape. We could include here detention centers for immigrants, customs posts and refugee camps. The non-places of image are best exemplified in theme parks and tourist resorts-all virtually identical from one corner of the globe to the other.

The idea that the supermodern world is filled with simulacra is shared by other thinkers. It was another French scholar, Jean Baudrillard (1994), who employed the term simulacrum to define something which is not a copy of the real but that actually exceeds reality and creates its own truth. This hyperreality of the supermodern Augé finds it not just in new constructions, but also in the restoration of heritage, which creates a sort of historical hyperreality. What is interesting is what the anthropologist opposes to heritage sites: ruins. "The contemplation of ruins, writes Augé (2003: 7), allows us to catch a fleeting glimpse of the existence of a time that is not the one about which history books speak or the one that restoration works try to resuscitate. It is a pure time, to which no date can be assigned”.

Although the existence of non-places has been questioned (Bender 2001: 78), it can still be argued that there are certainly spaces in supermodernity that if not totally devoid of identity, relationality or historicality, are at least hostile to the idea of memory and belonging. Archaeologists have started to study non-places in a way that is akin to De Certeau's (1984) approach to everyday tactics of resistance. Against the idea of monolithic non-places, researchers reveal the practices through which non-places can be 
appropriated and resisted. "The alienating qualities of these places are fragile: they can be challenged”, argue Hicks and Hicks (2006). Without negating the dismal aspects of non-places, in this case a retail center in Wales, Graves-Brown (2007) also points out ways in which the physical barriers that enclose the "concrete islands" that are malls are circumvented in practice. Harrison and Schofield (2010: 256-257) in turn, suggest that archaeology itself can become a critical practice: if non-places are presented as neutral and ahistorical, archaeology has to reveal "the specific histories of these places and the ways in which they are concealed from the public. The peeling carpet, the layers of paint, and the traces of previous styles of airport furniture all carry a sense of the specific history of the airport departure lounge, signalling to the passenger that he or she is in 'this' place rather than some other". A similar approach is that of geographer Tim Edensor (2005), whose work has focused on other kind of non-places: abandoned industrial spaces. Although they are commonly perceived as a black hole in the urban fabric, Edensor shows that they are also arenas for creative engagements with materiality, where the regimented space of the supermodern city is actively subverted. The heterodox uses to which these ruins are put are a hint of another possible city and alternative urban experiences. While this is a valuable approach that can reveal an unexpected side to supermodern spatiality, we can wonder: do we not run the risk of overlooking the power structures that support the existence of non-places by trying to find small cracks in the system? How destabilizing to supermodern power actually are the paths open in the gardens of a shopping center, a peeling carpet or the teenagers smashing windows in a derelict factory?

Non-places are just a variable of supermodern geographies. Other kinds of spaces exist. Bauman (2000: 98-104), following different authors, proposes a typology of mostly dystopic places, which he labels emic, phagic and empty (in addition to nonplaces). Emic places create spatial separations (prisons, ghettos), whereas phagic spaces digest people and suspend otherness-consumer spaces fit in this category. Empty places are those that lack meaning, "leftover places". I have suggested a category of place that tries to make sense of the politics involved in the spatial excesses of supermodernity: places of abjection. Like empty places, they are also a leftover and a memory gap. However, it is important to emphasize that places of abjection are characterized by an excess of wasted materiality: battlefields, scenarios of massacres, industrial disasters, shanty towns. When one walks around a war site of the last hundred years, one is struck by the enormity of material waste: concrete, cans and shells litter 
vast expanses of empty, forgotten land (FIGURE 2). A similar impression can be obtained in slums, whose messy material overabundance stands in stark contrast to the sanitized, empty spaces of privatopias (Penrose 2007: 34-35). Unlike other spaces of supermodernity, places of abjection are only produced by political processes of marginalization and exclusion of (subaltern) people, (abject) matter and (dissonant) memories.

\section{Time excess}

“The time is out of joint”. Hamlet’s words resound along Derrida’s book, Specters of Marx (2006). "Time is disarticulated, dislocated, dislodged, time is run down, on the run and run down, deranged, both out of order and mad. Time is off its hinges, time is off course, beside itself, disadjusted” (Derrida 2006: 20). This is a more eloquent way of describing the state of time in supermodernity than the usual idea of accelerated time. Because it is not only that things go faster or that there is a factual excess, as Augé and others suggests. It is also, more precisely, that time is out of joint, which is also saying that time is both unjust and anachronic (ibid.: 25). Derrida, then, links temporality and morality, both of which are put into crisis by supermodernity.

It is probably this feeling that has led archaeologists to focus on alternative, heterogeneous temporalities (Witmore 2007; Hamilakis 2011), which are also a matter of concern in other fields (De Landa 2000). Archaeologists working in the recent past have to be, more than any other practitioners, ready to appraise non-linear time to make sense of a world where time is deranged. They have to revalue other temporalities, those of subaltern and nonmodern communities, which still survive in the interstices of the supermodern world. They have to make visible these slower, bodily temporalities, as a way to challenge the disarticulated ephemerality of supermodern time. A good way of reclaiming other temporalities is showing its persistence in the present, the time of objects that anchor time, instead of disintegrating it: the time of immutable things, which has been forgotten. Think of a knife, an axe or a stone wall. They do not call the attention of students of material culture, which are fascinated by cell phones and i-pods. An archaeology of supermodernity does not only study what is new and changing, it should also vindicate the subaltern artefact that resists the annihilation of time: the humble, elementary object (Olivier 2008: 288).

Because the time of supermodernity is not only disjointed and accelerated, it is also a time that continuously abolishes itself. For supermodern societies, there is no past 
or future: only the instant (Bauman 2000: 125). There is an excess of present. From the point of view of material culture, the relationship of this temporality with planned obsolescence and fashion has already been noticed. Archaeology can, of course, study the ephemeral temporality of supermodern technologies, but it can do something else. Archaeology can show the collateral damages of instantaneity: living the instant, with a total disregard for sustainability in the long term, requires an intensified predation on the environment, which leaves a far-from-ephemeral trail of devastation (cf. GonzálezRuibal and Hernando 2010). The ephemerality of material culture is certainly not new: it was already noticed at the beginning of the supermodern period, when skyscrapers in New York were torn down almost as fast as they were being built, over a hundred years ago (Yablon 2010: 244-246). The supermodern metropolis is hollowed out of a past; it inhabits an amnesic present. Connerton (2009: 88) talks about "the reign of a perpetual present”. Here lies another possible contribution of archaeology: by excavating the foundations of post-mnemonic cities, the discipline can simultaneously show that other worlds are possible and that there exists a past. Such an assertion, under the prevailing memory regime, can become a truly political one, especially if this past destabilizes the cleansed histories of progress or romanticized heritage pastiches (Hall and Bombardella 2005).

\section{Material excess}

Material excess is one of the defining characteristics of supermodernity. However, sociologists and theorists have tended to downplay the relevance of matter and have preferred to focus instead on the less tangible aspects of supermodernity, either from a critical or celebratory point of view: networks (Castells 1996), fluidity (Bauman 2000), speed (Virilio 2002) and the virtual more generally. Capital flow, fast consumption, new media and intercontinental travel give the impression that we are leaving a dematerialized existence: Bauman (2000: 113-118) talks about the shift from a "heavy" to a "light modernity". But is supermodernity truly that light? I would contend that, on the contrary, society has never been heavier and that to consider it light is the result of a process of purification, sensu Latour (1993), that blackboxes the material foundations of supermodernity. I do not intend to rule out the metaphor of liquid modernity altogether, which I think is apt and insightful. The problem is that the metaphor can lead us to forget both the true weight of our present time and that this weight is not equally 
distributed. There are some regions of the world (those who suffer war or capitalist depredation), where supermodernity is heavier than in others.

The problem is that media gurus and journalists always tend to emphasize processes of virtualization. A good case in point is war, which is usually presented as a high-tech videogame. Yet the combat gear of supermodern soldiers is bulkier than ever: only their body armor can weight up to 15 kilos (Tyson 2009). And it does not matter how light a Predator drone is and that it is operated remotely, its effects are still strongly material and situated: rubble and splintered bones in a Pakistani or Yemeni village. Archaeology can be a counterbalance to the generalized perception of the world as plastic (Olsen 2003; González-Ruibal 2008: 252-254). An emphasis on fluidity and movement, in fact, may lead us to forget all the material strategies of fixation and circumscription deployed by supermodern powers: movement is always controlled. Those who move and the things that circulate have to be allowed to do so. It is a historical paradox that moments of high globalization come hand in hand with walls and fences: Hadrian's wall, the Great Chinese Wall, the US-Mexico border fence and the Israeli West Bank barrier.

Archaeologists have not been the only ones to have paid attention to materiality. Art has shown a fascination with material excess for the last three decades at least. Godfrey Reggio's Koyaanisqatsi (1982) is a powerful audiovisual account of supermodernity, in which the mass production and mass destruction of materiality are repeatedly overlapped. A similar aesthetics are deployed by Andreas Gursky (2008) in his monumental photographs of cities, buildings, and crowded spaces, and Burtynsky's (2009) equally vast depictions of supermodern landscapes altered to the extreme by heavy industry. These and similar works convey the impression of a deeply material world gone excessive, of superhuman scale and irreparable ecological damage and loss - things for which words alone cannot suffice: “a world beyond words" is the tagline of another visual experiment along this lines (Fricke 1992). However, it is important to bear in mind that the art of supermodern destruction is an art of the sublime, with the ethical problems that this entails.

Burke (1834: 32) famously defined the sublime as "Whatever is fitted in any sort to excite the ideas of pain and danger, that is to say, whatever is in any sort terrible, or is conversant about terrible objects, or operates in a manner analogous to terror”. Terror, in turn, is associated to power: power is sublime because it can inflict pain and terror and only when power is deprived of this ability, "you spoil it of everything sublime and 
it immediately becomes contemptible” (ibid.: 40). Yet the sublime is not only linked to terror and power, but also to pleasure and beauty: "When danger or pain press to nearly, they are incapable of giving any delight, and are simply terrible; but at certain distances, and with certain modifications, they may be, and they are, delightful” (ibid.: 33). This is what the art of supermodernity achieves: it creates a distance with terror and pain that renders the destruction of the world produced by supermodern power aesthetically pleasurable and in the last instance, safe and consumable. This can be noticed in Dan Dubowitz and architect Patrick Duerden's exhibition: Fascismo Abbandonato. They have been documenting abandoned buildings of the fascist period in northern Italy, particularly youth camps. Theirs is an evocative vision of a failed modernist dream. As it happens with other similar undertakings, the exhibition is aesthetically powerful—but perhaps too much. There is an unabashed aestheticization of the subject. Thus, Duerden and Dubowitz describe the ruins as 'huge and sublime, ${ }^{1}$ - a description that would have pleased Mussolini. Herein lies the difference between the work of art and the work of archaeology. Although the sublime is not absent —and does not have to be-in the archaeology of supermodernity (see Andreassen et al. 2010) or the critical in the work of art (Blocker 2009), in the balance between terror and beauty, it is terror and power that should prevail; disgust, rather than pleasure. Consider two examples of supermodern excess: garbage and violence.

In William Rathje's research on garbage, there is little room left for beauty (of the conventional kind, at least): what we have are mountains of highly-polluting rubbish or daily garbage fresh from the bin (Rathje and Murphy 1992). Likewise, the exhumations of victims of political violence disclose piles of bodies, an excess of shattered human matter, which has become a fossil-guide for supermodernity (Montero 2009) (FIGURE 4). However, archaeology does not only excel at revealing the abject: it also creates stories out of things-all things, no matter how humble or abject. With Gursky's photographs, we are left in awe, but this is a sublime awe similar to that produced by the manicured space of a military cemetery (Augé 2003: 103). Instead, by carefully dissecting ruins, locating artefacts, studying the relation of small objects and structures, and exploring the sites' afterlife, archaeologists can come up not just with a potent imagery, but also with detailed narratives. It is powerful stories that we obtain out of garbage from a landfill, a mass grave or the place of a disaster (Gould 2007). It is

\footnotetext{
${ }^{1}$ http://www.fermynwoods.co.uk/archive/water-tower/dan-dubowitz-patrick-duerden/
} 
also this production of narratives that allows archaeology to construct a critical discourse on supermodernity, not just to stare at it in astonishment and powerlessness. Archaeology, thus, combines a concern for the manifestation of materiality, akin to art, and a commitment to analyzing reality, that relates it to other social sciences.

\section{Future directions}

Supermodernity has been defined here as a period within modernity characterized by excess. I have defended that archaeology can make a contribution to understanding supermodernity by looking into the excesses of time, space and, particularly, materiality. While the overabundance of the spatial and the factual has often come under scrutiny, material excess has repeatedly escaped the gaze of theorists and it has mostly fallen to artists the task of manifesting it. Archaeologists, however, are in a good position to join artists in the examination of supermodern materialities. The study of late modernity has been too focused on the ethereal realms of hyperreality and virtuality: the complex semiotics of simulacra and networks have captured all the attention of scholars and philosophers. As opposed to this, I would argue that the mission of archaeology is to address the Real, sensu Slavoj Žižek: the Real is what resists symbolization, "the traumatic point which is always missed but none the less always returns, although we try-through a set of different strategies - to neutralize it, to integrate it into the symbolic order” (Žižek 1989: 69). Culture students abhor the Real precisely because it escapes hermeneutic efforts, but archaeologists are continuously facing the unconstituted, which is "not simply the unsaid, but the unsayable-it lies outside the said, outside discourse” (Buchli and Lucas 2001: 12). Referring to the Titanic, which has been transformed into a sublime object, Žižek (71) argues that "all the effort to articulate the metaphorical meaning of the Titanic is nothing but an attempt to domesticate the Thing by reducing it to its symbolic status, by providing it with a meaning”. What archaeologists have to do is to expose the excess of supermodernity beyond symbolization: the raw, traumatic Thing at the core of the Real. 